\title{
Effect of Socioeconomic Inequality on Overweight and Obesity in Children: A Review of Systematic Reviews
}

\author{
Fatemeh Mehravar*1, Reza Majdzadeh"1, Mohammadreza Honarvar², Mohammadjavad \\ Kabir $^{2}$, Shirin Maleki ${ }^{3}$
}

1. Department of Epidemiology and Biostatistics, School of Public Health, Tehran University of Medical Sciences, Tehran, Iran

2. Health Management and Social Development Research Center, Golestan university of Medical Sciences, Gorgan, Iran

3. Department of Occupational Therapy, School of Paramedical and Health, Zanjan University of Medical Sciences, Zanjan, Iran

\begin{abstract}
Background and objectives: Obesity has become a global epidemic. Previous studies have reported a relationship between obesity in adults and socioeconomic factors, but the results regarding such relationship in the case of childhood obesity have been inconsistent. Therefore, this study aimed to determine the relationship between socioeconomic inequalities and overweight/obesity in children.

Methods: All meta-analysis, systematic and descriptive or correlational reviews on obesity in children and adolescents that have been published in English between January 2001 and January 2019 were included in the study. We performed the search for articles in the following databases: MEDLINE, Embase, Web of Science, Cochrane Library and Google Scholar. Each review article was subjected to qualitative evaluation using the Grading of Recommendations Assessment, Development and Evaluation (GRADE) tool.

Results: Of 46 articles that met the inclusion criteria, five systematic reviews were included after carefully reading the abstract and the full text of the articles. The prevalence of overweight and obesity in children differed in different socioeconomic groups. Ethnicity was a confounding factor that could change this relationship.

Conclusion: Strong evidence supports the relationship between socioeconomic status and overweight or obesity in children. Therefore, it is recommended to consider the socioeconomic status when planning for control and prevention of childhood obesity.

Keywords: Inequality; socioeconomic; obesity; children

Received: 2019/11/20 $\quad$ Revised:2019/12/03 $\quad$ Published:2019/12/15

*Correspondence: Fatemeh Mehravar, Department of Epidemiology and Biostatistics, School of Public Health, Tehran University of Medical Sciences, Tehran, Iran

Tel: +98

Email: mehravar10261@yahoo.com
\end{abstract}




\section{INTRODUCTION}

In recent years, the prevalence of overweight and obesity in children has become a concern and a major risk factor for non-communicable diseases, such as cardiovascular disease, diabetes and some types of cancer in children (1). According to the latest report by the World Health Organization, childhood obesity is one of the most serious public health challenges of the $21^{\text {st }}$ century, which is steadily expanding in many low- and middleincome countries, especially in urban areas (2). The prevalence of obesity in children is increasing at an alarming rate in a way that over 41 million children under the age of five were overweight in 2016. Almost half of overweight children under the age of five live in Asia and a quarter of them live in Africa (3). There are different methods to measure obesity and overweight in children and adolescents, but there is no single definition for these problems. Nevertheless, body mass index (BMI) is commonly used as an indicator of overweight or obesity, which is obtained by dividing weight $(\mathrm{kg})$ by height $(\mathrm{cm})$ squared. A BMI of lower than $5^{\text {th }}, 85^{\text {th }}$ to $94^{\text {th }}$ and more than $95^{\text {th }}$ percentile indicates healthy weight, overweight and obesity, respectively $(4,5)$.

The relationship between socioeconomic inequality and children's health has been the focus of many studies (6). Inequality is an issue at the social level that imposes a high burden and cost on the society. Individuals gain different socioeconomic positions based on occupational status and level of education and income (7). Conceptually, socioeconomic inequality in children's health is defined as differences in the incidence or prevalence of health problems, such as obesity and overweight among populations with low and high socioeconomic status (8).

Previous studies have reported a correlation between obesity in adults and socioeconomic factors $(9,10)$, but results of the studies on childhood obesity have been inconclusive (11). The present study is a systematic review of published studies with the aim of determining the relationship between socioeconomic inequalities and childhood overweigh or obesity.

\section{MATERIALS AND METHODS}

The terms "obesity", "overweight", "child", "socioeconomic" and "inequality" and their combinations with and/or were searched in the title, abstract or keyword sections of MEDLINE, Embase, Web of Science, Cochrane Library and the Google Scholar databases (Appendix 1).

Appendix 1. Search strategies used in the study

\begin{tabular}{|c|c|c|}
\hline Database & Search strategy & $\begin{array}{c}\text { Number of } \\
\text { articles } \\
\text { included in the } \\
\text { study }\end{array}$ \\
\hline MEDLINE/PubMed & $\begin{array}{l}\text { (((((((() } \\
\text { OR metanalysis[Publication Type]) OR synthesis[Publication Type]) AND } \\
\text { obes*[Title/Abstract]) OR overweight[Title/Abstract]) AND } \\
\text { child*[Title/Abstract]) OR adolescent[Title/Abstract]) AND } \\
\text { socioeconomic[Title/Abstract]) AND inequal*[Title/Abstract] }\end{array}$ & $\begin{array}{l}248 \text { titles, } 26 \\
\text { were selected } \\
\text { by title }\end{array}$ \\
\hline Cochrane Library & $\begin{array}{l}\text { 'socioeconomic in Title Abstract Keyword AND child* in Title Abstract } \\
\text { Keyword AND obes* in Title Abstract Keyword OR overweigh in Title } \\
\text { Abstract Keyword - with Cochrane Library publication date Between Jan } \\
2001 \text { and Jan 2019, in Cochrane Reviews (Word variations have been } \\
\text { searched)' }\end{array}$ & $\begin{array}{l}8 \text { titles, none } \\
\text { were selected } \\
\text { by title }\end{array}$ \\
\hline
\end{tabular}


Journal of Clinical and Basic Research (JCBR). 2019; 3(4): P 23-30.

\begin{tabular}{|c|c|c|}
\hline $\begin{array}{l}\text { Web of Science Core } \\
\text { Collection }\end{array}$ & $\begin{array}{l}\text { TITLE: (socioeconomic) AND TITLE: (obesity) OR TITLE: (overweight) } \\
\text { AND TITLE: (inequali*) AND TITLE: (child*) AND TITLE: } \\
\text { (adolescent) Timespan: } 2001-2019 . \text { Indexes: SCI-EXPANDED, SSCI, } \\
\text { CPCI-S, CPCI-SSH, ESCI. }\end{array}$ & $\begin{array}{c}10 \text { titles, } 3 \text { were } \\
\text { selected by } \\
\text { title. }\end{array}$ \\
\hline Embase & $\begin{array}{c}\text { 'socioeconomic':ti AND 'inequal*':ab,ti AND 'child*':ab,ti AND } \\
\text { 'obes*':ab,ti AND 'review':ab,ti }\end{array}$ & $\begin{array}{l}412 \text { titles, } 17 \\
\text { were selected } \\
\text { by title. }\end{array}$ \\
\hline
\end{tabular}

All meta-analysis, systematic and descriptive or correlational reviews on obesity in children and adolescents that have been published in English between January 2001 and January 2019 were included in the study. Studies that were not available in full text were excluded.
Selection of articles was done based on titles and abstracts and then on the inclusion criteria. The full text of the articles was read in detail (Figure 1). References of the included articles were also used to manually search for related articles.

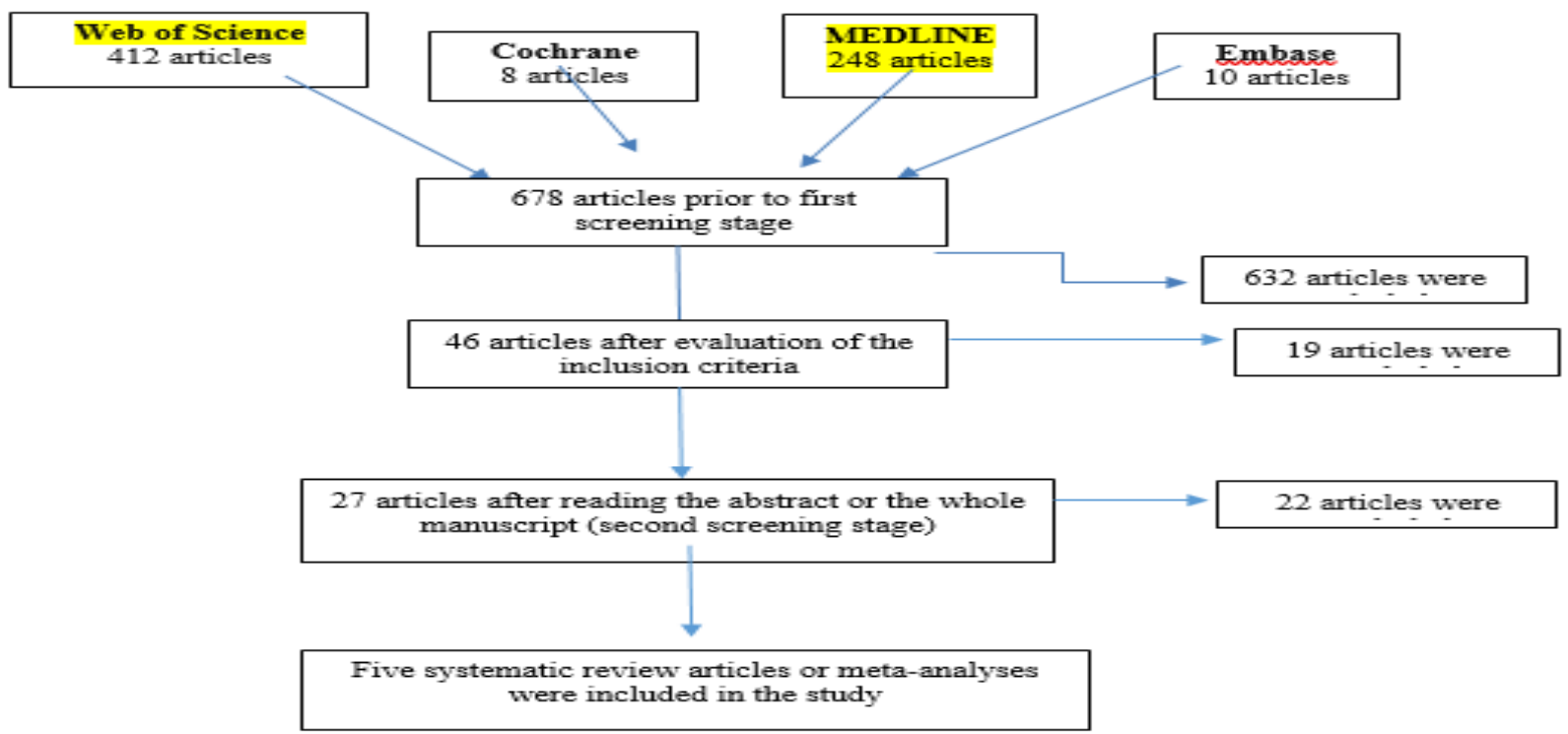

Figure 1. Flowchart of article selection process on the relationship between socioeconomic inequalities and obesity

The search strategy in the MEDLINE database was as follows: meta-analysis or systematic review or synthesis were selected in the publication type section. In the advance search section, the keywords (overweight, adolescent, child*, obes* and inequal*) and their combination (using and) were put in the title and abstract. Overall, 248 articles were searched, 26 of which were selected. The search strategies for other databases are listed in appendix 1. The mesh term from the MEDLINE database was used to find relevant synonyms.

For quality assessment, first, the references of the review articles were analyzed using the critical appraisal skills programs (CASP) with an emphasis on the qualitative evaluation methodology (12). Then, each article was 
Journal of Clinical and Basic Research (JCBR). 2019; 3(4): P 23-30.

assessed using the grading of recommendations assessment, development and evaluation (GRADE) tool, which is an appropriate process for evaluating the quality and power of evidence and health-related recommendations in systematic reviews and guidelines (13).

\section{RESULTS}

After reading the manuscripts of 46 articles that met the inclusion criteria, five systematic reviews were selected (Table 1). Obesity indices used in the review articles included height, weight, BMI z-scores, waist circumference, waist-to-hip ratio, body fat percentage, skin thickness and growth charts. The socioeconomic indices used in the articles included parents' education level and occupation, household income and neighborhood or school socioeconomic index. All articles analyzed in this review were observational, longitudinal and crosssectional, non-interventional studies.

Table 1. Characteristics of systematic review articles that were included in the study of relationship between socioeconomic inequality and obesity

\begin{tabular}{|c|c|c|c|c|c|c|}
\hline $\begin{array}{c}\text { Author / } \\
\text { Year }\end{array}$ & Main objective(s) & $\begin{array}{l}\text { Method of } \\
\text { study }\end{array}$ & Inclusion criteria & $\begin{array}{c}\text { Database(s) } \\
\text { used in the } \\
\text { study }\end{array}$ & $\begin{array}{l}\text { Search } \\
\text { time }\end{array}$ & $\begin{array}{c}\text { Country of } \\
\text { study }\end{array}$ \\
\hline $\begin{array}{l}\text { El-Sayed } \\
2012(13)\end{array}$ & $\begin{array}{l}\text { Reviewing articles on } \\
\text { the relationship } \\
\text { between } \\
\text { socioeconomic status } \\
\text { and childhood } \\
\text { obesity in the UK }\end{array}$ & $\begin{array}{l}\text { Longitudinal } \\
\text { cross-sectional }\end{array}$ & $\begin{array}{l}\text { 1. Articles that have } \\
\text { examined the } \\
\text { relationship } \\
\text { between } \\
\text { socioeconomic } \\
\text { status and obesity } \\
2 . \text { Non- } \\
\text { interventional } \\
\text { articles } \\
\text { 3- Age of } 2 \text { to } 18 \\
\text { years }\end{array}$ & MEDLINE & $\begin{array}{l}1980- \\
2010\end{array}$ & $\begin{array}{c}\text { New York, } \\
\text { USA }\end{array}$ \\
\hline $\begin{array}{c}\text { Chung } \\
2016 \text { (12) }\end{array}$ & $\begin{array}{c}\text { Investigating changes } \\
\text { in obesity trends in } \\
\text { different } \\
\text { socioeconomic } \\
\text { groups in advanced } \\
\text { countries }\end{array}$ & Cohort & $\begin{array}{l}\text { 1. Articles that have } \\
\text { reported the } \\
\text { prevalence of } \\
\text { overweight or } \\
\text { obesity based on the } \\
\text { socioeconomic } \\
\text { status } \\
\text { 2. Articles on } \\
\text { children and } \\
\text { adolescents }\end{array}$ & $\begin{array}{l}\text { MEDLINE } \\
\text { Embase, } \\
\text { CINAHL, } \\
\text { Scopus and } \\
\text { Cochrane } \\
\text { Library }\end{array}$ & $\begin{array}{l}1990- \\
2015\end{array}$ & $\begin{array}{c}\text { Melbourne, } \\
\text { Australia }\end{array}$ \\
\hline $\begin{array}{c}\text { Shrewsbury } \\
2007 \text { (16) }\end{array}$ & $\begin{array}{c}\text { Investigating the } \\
\text { relationship between } \\
\text { socioeconomic level } \\
\text { and obesity in } \\
\text { school-age children } \\
\text { in developed Western } \\
\text { countries }\end{array}$ & $\begin{array}{l}\text { Cross- } \\
\text { sectional }\end{array}$ & $\begin{array}{l}\text { 1. Cross-sectional } \\
\text { studies } \\
\text { 2. Studies in the } \\
\text { specific period } \\
\text { 3. Children and } \\
\text { adolescents }\end{array}$ & MEDLINE & $\begin{array}{l}1990- \\
2005\end{array}$ & $\begin{array}{l}\text { London, } \\
\text { UK }\end{array}$ \\
\hline $\begin{array}{c}\text { Dinsa } \\
2012(14)\end{array}$ & $\begin{array}{l}\text { Reviewing articles on } \\
\text { the relationship } \\
\text { between } \\
\text { socioeconomic status } \\
\text { and childhood } \\
\text { obesity in low- and }\end{array}$ & Observational & $\begin{array}{l}\text { 1. Cross-sectional } \\
\text { studies } \\
\text { 2. Studies in the } \\
\text { specific period } \\
\text { 3. Children and } \\
\text { adolescents }\end{array}$ & $\begin{array}{c}\text { MEDLINE } \\
\text { and Google } \\
\text { Scholar }\end{array}$ & $\begin{array}{l}2004- \\
2011\end{array}$ & $\begin{array}{l}\text { Norwich, } \\
\text { UK }\end{array}$ \\
\hline
\end{tabular}


Journal of Clinical and Basic Research (JCBR). 2019; 3(4): P 23-30.

\begin{tabular}{|c|c|c|c|c|c|c|}
\hline & $\begin{array}{l}\text { middle-income } \\
\text { countries }\end{array}$ & & & & & \\
\hline $\begin{array}{l}\text { Tamayo } \\
2010(15)\end{array}$ & $\begin{array}{l}\text { Determining the } \\
\text { relationship of } \\
\text { socioeconomic status } \\
\text { with incidence of } \\
\text { diabetes, obesity and } \\
\text { metabolic disorders } \\
\text { in children }\end{array}$ & $\begin{array}{c}\text { Longitudinal, } \\
\text { population } \\
\text { based }\end{array}$ & $\begin{array}{l}\text { 1. Articles that have } \\
\text { reported the } \\
\text { prevalence of } \\
\text { diabetes, obesity } \\
\text { and metabolic } \\
\text { disorders. } \\
\text { 2. Population-based } \\
\text { studies that have } \\
\text { evaluated the } \\
\text { relationship } \\
\text { between } \\
\text { socioeconomic } \\
\text { status and obesity } \\
3 . \text { Homogeneity of } \\
\text { data }\end{array}$ & MEDLINE & $\begin{array}{l}1994- \\
2010\end{array}$ & Germany \\
\hline
\end{tabular}

Of the five review articles, two $(12,13)$ were only on the results of economically developed countries and one article (14) was on developing countries. The rest $(15,16)$ were on both developed and developing countries. Only one article (12) completely covered the MEDLINE, Embase, CINAHL, Web of Science and Cochrane Library databases, while the other four used the MEDLINE database only. Although two articles $(12,13)$ had higher grades due to publication bias, other articles (14-16) received a negative score on this item. From the inconsistency aspect of the GRADE tool, only one (12) of the five articles referred to heterogeneity, while the other articles had reduced scores. Articles by El-Sayed (13) and Dinsa (14) had not separately reported important confounding factors such as age, gender or ethnicity, but the rest of the articles received a positive score in terms of potential confounders.

The paper by Chung et al. (12) published in the journal of Obesity Reviews obtained the highest grade of evidence quality according to GRADE (Table 2).

Table 2. Qualitative analysis of systematic review articles using the GRADE tool to study the relationship between socioeconomic inequality and obesity

\begin{tabular}{|c|c|c|c|c|c|c|c|}
\hline Study & $\begin{array}{l}\text { Number } \\
\text { of studies } \\
\text { reviewed }\end{array}$ & $\begin{array}{c}\text { Study } \\
\text { limitations }\end{array}$ & Inconsistency & Indirectness & Imprecision & $\begin{array}{c}\text { Publication } \\
\text { bias }\end{array}$ & $\begin{array}{l}\text { Overall } \\
\text { quality of } \\
\text { evidence }\end{array}$ \\
\hline $\begin{array}{l}\text { El-Sayed, } \\
2012(13)\end{array}$ & 23 & $\begin{array}{l}\text { No: Low } \\
\text { risk }\end{array}$ & Low & No & $\begin{array}{c}\text { Not } \\
\text { applicable }\end{array}$ & Low & $\begin{array}{c}\oplus \oplus \mathrm{OO} \\
\text { Low }\end{array}$ \\
\hline $\begin{array}{c}\text { Dinsa, } 2012 \\
(14)\end{array}$ & 11 & $\begin{array}{c}\text { Yes: } 3 / 5 \\
\text { high risk } \\
1 \text { level } \\
\text { down }\end{array}$ & Moderate & No & $\begin{array}{c}\text { Not } \\
\text { applicable }\end{array}$ & $\begin{array}{c}\text { Not } \\
\text { observed }\end{array}$ & $\begin{array}{c}\oplus \oplus \oplus \mathrm{O} \\
\text { Moderate }\end{array}$ \\
\hline $\begin{array}{c}\text { Chung, } 2016 \\
\text { (12) }\end{array}$ & 30 & $\begin{array}{l}\text { No: Low } \\
\text { risk }\end{array}$ & $\begin{array}{c}\text { No } \\
\text { inconsistency }\end{array}$ & No & $\begin{array}{c}\text { Not } \\
\text { applicable }\end{array}$ & Low & $\begin{array}{c}\oplus \oplus \oplus \oplus \\
\text { High }\end{array}$ \\
\hline
\end{tabular}


Journal of Clinical and Basic Research (JCBR). 2019; 3(4): P 23-30.

\begin{tabular}{|c|c|c|c|c|c|c|c|}
\hline \hline & & & & & & \\
\hline $\begin{array}{c}\text { Tamayo, } \\
2010 \text { (15) }\end{array}$ & 10 & $\begin{array}{c}\text { No: Low } \\
\text { risk }\end{array}$ & Not applicable & No & $\begin{array}{c}\text { Not } \\
\text { applicable }\end{array}$ & $\begin{array}{c}\text { Not } \\
\text { observed }\end{array}$ & $\begin{array}{c}\oplus \oplus \oplus \mathrm{O} \\
\text { Moderate }\end{array}$ \\
\hline $\begin{array}{c}\text { Shrewsbury, } \\
2008 \text { (16) }\end{array}$ & 45 & $\begin{array}{c}\text { Yes: 1 high } \\
1 \text { low risk } \\
1 \text { level } \\
\text { down }\end{array}$ & Low & No & $\begin{array}{c}\text { Not } \\
\text { applicable }\end{array}$ & $\begin{array}{c}\text { Not } \\
\text { observed }\end{array}$ & Very Low \\
\hline
\end{tabular}

The main question was whether recent trends in childhood ( 2 to 18 years old) obesity and overweight changed in developed countries considering the socioeconomic status. The study found that the prevalence of obesity and overweight in children continued to increase in populations with a high socioeconomic status, while this increasing trend was slower in populations with a lower socioeconomic status (across all age groups).

The study by El-Sayed et al. (13) published in the journal of Obesity Facts aimed to determine the impact of socioeconomic inequalities on the risk of childhood obesity in the UK while focusing on regional indicators. The study reviewed 23 longitudinal and crosssectional papers that had been done on arealevel socioeconomic indicators. They found a direct link between childhood obesity and area deprivation levels. The article also showed that household income, parents' education level, household size, free school meals, father's occupational status and social class status of the head of household are influential factors in childhood obesity and overweight.

Tamayo et al. reported that metabolic disorders and type 2 diabetes during childhood could be predictors of obesity. Dinsa et al. (14) reviewed 11 articles on childhood obesity and reported that the prevalence of childhood obesity varies from 1 to $18 \%$, with a higher incidence rate in boys. It also stated that the prevalence of obesity was directly related to the increase in countries' income. India and Vietnam had the lowest prevalence of childhood obesity, while
Guatemala and Ukraine had the highest prevalence of childhood obesity. They also found a positive relationship between socioeconomic status and obesity regardless of age, gender, level of obesity, level of Gini coefficient per capita and measurement indicators.

None of the articles examined socioeconomic inequality at both the individual/family or regional levels. In addition, none of the review articles had performed a meta-analysis on the results of the various studies. Another limitation of the analyzed articles was failure to investigate the causal relation between socioeconomic status and childhood obesity.

\section{DISUCSSION}

Our findings showed that the prevalence of overweight and obesity in children varies among different socioeconomic groups in all systematic review articles published from 2001 to January 2019. In developed countries, the prevalence of childhood obesity is higher in those with a lower socioeconomic status (12). However, in developing countries or countries with a low human development index, the prevalence of childhood obesity is higher in families with a higher socioeconomic status (14). The prevalence of obesity and overweight in children is rising worldwide, with an increasing trend in populations with higher socioeconomic status $(8,12,17)$.

Although previous studies have demonstrated the relationship of obesity with age and gender in adults, no study has yet determined such relationship in the case of childhood 
obesity. Some evidence suggests that there may be a direct, positive link between socioeconomic status and obesity in adult men and women in low-income countries. In such countries, a higher income level or education level increases the likelihood of obesity. In middle-income countries, there is an inverse relationship between obesity among adult women and income or education level $(13,14)$.

One of the limitations of the present study is that we merely examined the association between socioeconomic status and obesity, not strengths and effect size. Given that all evaluated articles were systematic reviews and not meta-analyses, we were unable to draw a quantitative conclusion on this issue. Nevertheless, this paper is the first to analyze published secondary evidence on the relationship of socioeconomic status with childhood obesity using the GRADE tool. We believe that the results of the present study could be beneficial for health policy makers.

\section{CONCLUSION}

There is a relationship between socioeconomic status and overweight or obesity in children. Therefore, it is recommended to consider the socioeconomic status when planning for control and prevention of childhood obesity.

\section{ACKNOWLEGDMENTS}

The authors would like to thank the academic staff of the Department of Epidemiology and Biostatistics at Tehran University of Medical Sciences and Health and Social Development Research Center at Golestan University of Medical Sciences for their spiritual support.

\section{DECLARATIONS \\ Funding}

Not applicable.

\section{Ethics approvals and consent to participate} Not applicable.

\section{Conflict of interest}

The authors declare that there is no conflict of interest regarding the publication of this article.

\section{REFERENCES}

1. James WPT. Obesity: A Global Public Health Challenge. Clinical chemistry. 2018;64(1):24-9. [DOI:10.1373/clinchem.2017.273052]

2. Phantumvanit $\mathrm{P}$, Makino $\mathrm{Y}$, Ogawa $\mathrm{H}$, Rugg-Gunn A, Moynihan P, Petersen PE, et al. WHO global consultation on public health intervention against early childhood caries. Community dentistry and oral epidemiology. 2018;46(3):280-7. [DOI:10.1111/cdoe.12362]

3. Abarca-Gómez L, Abdeen ZA, Hamid ZA, Abu-Rmeileh NM, Acosta-Cazares B, Acuin C, et al. Worldwide trends in body-mass index, underweight, overweight, and obesity from 1975 to 2016: a pooled analysis of 2416 populationbased measurement studies in 128. 9 million children, adolescents, and adults. The Lancet. 2017;390(10113):2627-42. [DOI:10.1016/S01406736(17)32129-3]

4. Akhavan-Karbasi S, Fallah R, Golestan M, Sadr-Bafghi M. Prevalence and risk factors of obesity and overweight among primary school children in Yazd. SSU_Journals. 2009;16(5):8-13. 5. Caballero B. The global epidemic of obesity: an overview. Epidemiologic reviews. 2007;29(1):1-5. [DOI:10.1093/epirev/mxm012]

6. Cheng TL, Goodman E. Race, ethnicity, and socioeconomic status in research on child health. Pediatrics.

2015;135(1):e225-e37.

[DOI:10.1542/peds.2014-3109]

7. Walsh B, Cullinan J. Decomposing socioeconomic inequalities in childhood obesity: Evidence from Ireland. Econ Hum Biol. 2015;16:60-72. [DOI:10.1016/j.ehb.2014.01.003]

8. Hardy L, Mihrshahi S, Gale J, Drayton B, Bauman A, Mitchell J. 30-year trends in overweight, obesity and waist-to-height ratio by socioeconomic status in Australian children, 1985 to 2015. Int J Obes. 2017;41(1):76. [DOI:10.1038/ijo.2016.204]

9. El-Sayed AM, Scarborough P, Galea S. Unevenly distributed: a systematic review of the 
Journal of Clinical and Basic Research (JCBR). 2019; 3(4): P 23-30.

health literature about socioeconomic inequalities in adult obesity in the United Kingdom. BMC public health. 2012;12(1):18. [DOI:10.1186/14712458-12-18]

10. Olstad D, Teychenne M, Minaker L, Taber D, Raine K, Nykiforuk C, et al. Can policy ameliorate socioeconomic inequities in obesity and obesity-related behaviours? A systematic review of the impact of universal policies on adults and children. Obesity Reviews. 2016;17(12):1198-217. [DOI:10.1111/obr.12457]

11. Wang Y. Cross-national comparison of childhood obesity: the epidemic and the relationship between obesity and socioeconomic status. International journal of epidemiology. 2001;30(5):1129-36. [DOI:10.1093/ije/30.5.1129]

12. Chung A, Backholer K, Wong E, Palermo C, Keating C, Peeters A. Trends in child and adolescent obesity prevalence in economically advanced countries according to socioeconomic position: a systematic review. Obesity reviews. 2016;17(3):276-95. [DOI:10.1111/obr.12360]

13. El-Sayed AM, Scarborough P, Galea S. Socioeconomic inequalities in childhood obesity in the United Kingdom: a systematic review of the literature. Obesity facts. 2012;5(5):671-92. [DOI:10.1159/000343611]

14. Dinsa GD, Goryakin Y, Fumagalli E, Suhrcke M. Obesity and socioeconomic status in developing countries: a systematic review. Obesity reviews. 2012;13(11):1067-79. [DOI:10.1111/j.1467-789X.2012.01017.x]

15. Tamayo T, Herder C, Rathmann W. Impact of early psychosocial factors (childhood socioeconomic factors and adversities) on future risk of type 2 diabetes, metabolic disturbances and obesity: a systematic review. BMC public health. 2010;10(1):525. [DOI:10.1186/1471-2458-10$525]$

16. Shrewsbury V, Wardle J. Socioeconomic status and adiposity in childhood: a systematic review of cross-sectional studies 1990-2005. Obesity. 2008;16(2):275-84.

[DOI:10.1038/oby.2007.35]

17. Zhang Y-x, Wang Z-x, Zhao J-s, Chu Z-h. Trends in overweight and obesity among rural children and adolescents from 1985 to 2014 in
Shandong, China. European journal of preventive cardiology. 2016;23(12):1314-20.

[DOI:10.1177/2047487316643830] 